BENHA VETERINARY MEDICAL JOURNAL, VOL. 32, No. 1:59 - 66, MARCH, 2017

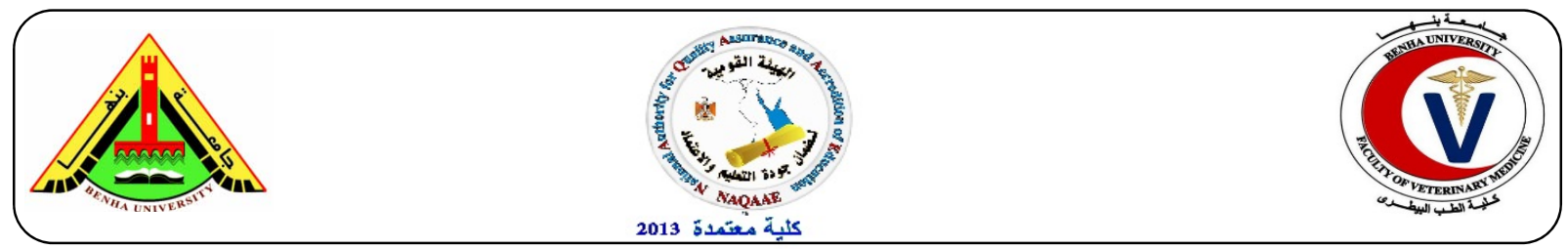

\title{
Biochemical effect of cranberry extract on experimentally induced myocardial infarction.
}

\author{
Hussien A. Ali ${ }^{1}$, Omnia A mahmoud ${ }^{1}$, Mohammed A. Hussein ${ }^{2}$, Mariam S. Mohammed ${ }^{3}$ \\ ${ }^{1}$ Department of Biochemistry, Faculty of Veterinary Medicine, Benha University. \\ ${ }^{2}$ Department of Biochemistry, Faculty of Pharmacy, October 6 University.
}

\begin{abstract}
A B S T R A C T
Myocardial infarction (MI) is characterized by an inequity of coronary blood supply and demand, which results in myocardial ischemic injury and damages the cardiomyocytes. Isoproterenol (ISO) is a synthetic catecholamine cause toxicity leading to severe stress in the myocardium of experimental animals. The aim of the present article is to investigate cardioprotective activity of cranberry extract against ISO-induced cardiotoxicity in adult rats. Oral administration of cranberry extract at a concentration of 75 and $150 \mathrm{mg} / \mathrm{kg}$ b.wt. daily for 28 days showed a significant protection againstinduced alteration in plasma total cholesterol (TC), triacyclglycerols (TG), high density lipoprotein (HDL-C), low density lipoprotein (LDL-C), tumor necrosis factor-alpha (TNF- $\alpha$ ) and nitric oxide (NO) as well as cardiac superoxide dismutase (SOD), glutathione peroxidase (GPx), reduced glutathione (GSH), catalase (CAT) levels. In addition, cranberry extract reduced plasma Creatine kinase-MB (CK-MB), lactate dehydrogenase (LDH) and aspartate aminotransferase (AST) as well as cardiac thiobarbituric acid reactive substances (TBARS) levels (MDA) as compared to control group. In conclusion, cranberry extract renders resiliency against isoproterenol cardiotoxicity due to its antioxidant and free radical scavenging activity.
\end{abstract}

Keywords: Cranberry extract, isoproterenol, myocardial infarction, antioxidant

(http://www.bvmj.bu.edu.eg)

(BVMJ-32(1):59-66, 2017)

\section{INTRODUCTION:}

Cardiovascular disease (CVD) is a major global cause of mortality in the developed countries. Intravascular thrombogenesis, the main pathogenic mechanism of the coronary artery disease $(\mathrm{CAD})$, is influenced by a complex interplay of procoagulant, anticoagulant, fibrinolytic, endothelial damage, dysfunction and inflammatory processes (Naghavi et al., 2003). The traditional theory for causation of CAD centers on a complex interplay between genetic and environmental, modifiable and non-modifiable risk factors setting into motion an inflammatory cascade of monocyte migration, lipid oxidation and atheromatous plaque formation (Berenson et al., 1998). Isoproterenol is a synthetic catecholamine that has positive inotropic and chronotropic effect. At therapeutic doses, it increases cardiac output, however when administered in large doses it was reported to cause severe oxidative stress in the myocardium leading to necrosis of the left ventricular heart muscle (Alcantara et al., 2011). Isoproterenol generates free radicals by the process of auto-oxidation and this free radical mediated oxidative stress was believed to be the mechanistic pathway via which isoproterenol induced necrosis (Almagro et al.,
2015). ISO causes excessive production of free radicals which induce lipid peroxidation (LPO) that causes irreversible damage to the myocardial membrane (Sathish et al., 2003).

Humans have evolved with antioxidant systems to protect against free radicals and ROS. These systems include some antioxidants produced in the body (endogenous) and others obtained from the diet (exogenous) (Chen et al., 2012). The first include enzymatic defenses, such as glutathione peroxidase, catalase, and superoxide dismutase, which metabolize superoxide, hydrogen peroxide, and lipid peroxides, thus preventing most of the formation of the toxic ROS (Chen et al., 2012). Plants vegetables and spices used in folk and traditional medicine have gained wide acceptance as one of the main sources of prophylactic and chemopreventive drug discovery and development (Ebenezer and Farombi, 2011; Mates et al., 1999). Cranberry ranks high among fruit in both antioxidant quality and quantity (Seef et al., 2001; Vinson et al., 2001) because of its substantial flavonoid content and a wealth of phenolic acids. Cranberry extracts rich in these compounds reportedly inhibit oxidative processes including 
oxidation of low-density lipoproteins (Porter et al., 2001; Yan et al., 2002), oxidative damage to neurons during simulated ischemia (Neto et al., 2005), and oxidative and inflammatory damage to the vascular endothelium (Youdim et al., 2002). The antioxidant properties of the phenolic compounds in cranberry fruit may contribute to the observed antitumor activities of cranberry extracts. Plant-derived fraction are rich sources of volatile terpenoids and phenolic compounds (Ebrahimzadeh et al., 2009). terpenoids are known to have potential to prevent obesity and have been used in aroma therapy for obese middle-aged women. Phenolic compounds extracted from plants may have antioxidant activity that could mitigate tumor-related complications, including atherosclerosis and some cancers (da Silva et al., 2009; De'corde' et al., 2009; Ebrahimzadeh et al., 2009; Han et al., 2003). Not surprisingly, plants such as cranberry extract contain high levels of poly-phenols (Ebrahimzadeh et al., 2009; Porter et al., 2001), which are excellent scavengers of reactive and represent a promising renal protective effect. The aim of the present article was to investigate cardioprotective activity of cranberry extract against ISO-induced cardiotoxicity in adult rats.

\section{MATERIALS AND METHODS}

\subsection{Chemicals and dosage:}

Dose of Cranberry:

Cranberry extract was purchased from Virgin Extracts (TM), China. Cranberry was given to female rat with $1 / 150 \mathrm{LD}_{50}(75 \mathrm{mg} / \mathrm{kg}$. bw. $)$ and $1 / 75 \mathrm{LD}_{50}(150 \mathrm{mg} / \mathrm{kg}$. bw. ) daily for 4 weeks by oral gastric gavage tube. Isoproterenol $(100 \%)$ and (Vitamin C, 100\%) were obtained from Merck Ltd., Germany.

\subsection{Experimental Animals:}

This experiment was conducted in accordance with guidelines established by the Animal Care and use Committee of Faculty of Veterinary Medicine, Benha University, Egypt. 60Adult male rats weighting around $180 \pm 10 \mathrm{gms}$ were purchased from National Cancer Institute, Cairo University. They were individually housed in cages in an airconditioned room with a temperature of $22 \pm 2^{\circ} \mathrm{C}$, a relative humidity of $60 \%$, and an 8:00 to $20: 00$ light cycle. During the acclimatization period, animals were supplied with a regular diet ad libitum.

\subsection{Experimental design:}

This experiment was carried out to examine the biochemical effect of cranberry on induced myocardial infarction. Groups of animals each consisting of 10 rats were treated daily for 28 days as follows: Group (1): Normal; was given normal diet for 28 days (Abdel-Maksoud et al., 2015). Group (2): Positive control; was given isoproterenol $(150 \mathrm{mg} / \mathrm{kg}$ b.w.) suspended in saline subcutaneously with a single dose at the 21 day (Liu, 2013). Group (3): was treated with Cranberry extract $(75 \mathrm{mg} / \mathrm{kg}$.b.w., orally) daily + isoproterenol $(100 \mathrm{mg} / \mathrm{kg} . \mathrm{b} . \mathrm{w}) \quad$ suspended in saline subcutaneously with a single dose at the 21 day (Abdel-Maksoud et al., 2015). Group (4): was treated with Cranberry extract $(150 \mathrm{mg} / \mathrm{kg}$. b.w., orally) daily + isoproterenol (100mg/kg.b.w.,) suspended in saline subcutaneously with a single dose at the 21 day (Abdel-Maksoud et al., 2015). Group (5): Was treated with Vitamin C (500 $\mathrm{mg} / \mathrm{kg}$. b.w) orally daily + isoproterenol $(100 \mathrm{mg} / \mathrm{kg} . \mathrm{b} . \mathrm{w}) \quad$ suspended in saline subcutaneously with a single dose at the 21 day (Luo et al., 1995). Group (6): Was treated with Vitamin C (1000 mg/kg.b.w) orally daily + isoproterenol $(100 \mathrm{mg} / \mathrm{kg}$. b.w $)$ suspended in saline subcutaneously with a single dose at the 21 day (Luo et al., 1995). At the end of the study, all rats were sacrificed blood was collected, centrifuged, and plasma was used freshly for estimation of CKMB according to the method of Gerhardt and Waldenström (1979), lactate dehydrogenase (LDH) according to the method of King (1965) and Aspartate transaminases (AST) activities according to the method of Reitman and Frankel (1957) in plasma were determined using biodiagnostic kits. TNF- $\alpha, \mathrm{NO}$ and interleukin 22 gene expression levels were estimated in heart homogenate by the methods described by Beyaert and Fiers (1998); Miranda et al. (2001), respectively. Also, TBARs and GSH levels in blood and heart were done by the methods described by Chanarin (1989); Nichans and Samulelson (1968), respectively. Blood and heart superoxide dismutase (SOD) and catalase (CAT) activities were carried out (Marklund and Marklund, 1974; Sinha, 1972), respectively. Blood Hemoglobin and Plasma and heart for Total Protein were done by methods described by Van Kampen and Zijlstra (1961); Weichselbaum (1946) respectively. Plasma triglycerides, total cholesterol and HDL- cholesterol were determined using commercially available kits (Asan and Youngdong Pharmaceutical Co., Korea) according to the methods of Allain et al. (1974); Burnstein et al. (1970); Fossati and Prencipe (1982), respectively. Plasma LDL-cholesterol level was calculated by formula $($ LDL-cholesterol $=$ total cholesterol triglycerides/5 - HDL-cholesterol). 


\subsection{Statistical analysis}

All the grouped data were statistically evaluated with SPSS (2012). Hypothesis testing methods included one way analysis of variance (ANOVA) followed by least significant difference (LSD) test. $P$ values of less than 0.05 were considered to indicate statistical significance. All the results were expressed as mean $\pm \mathrm{SD}$ for eight separate determinations.

\section{RESULTS}

Table (1) revealed a significant elevation in plasma cholesterol, triglyceride and low density lipoprotein (LDL) as well as significant reduction in high density lipoprotein (HDL) $(p<0.05)$, in the second group which represents isoproterenol $(100 \mathrm{mg} / \mathrm{kg})$ treated group of rats compared with control group. The administration of cranberry extract ( 75 and $150 \mathrm{mg} / \mathrm{kg}$.b.w.) and vitamin C (500 and $1000 \mathrm{mg} / \mathrm{kg}$ bw.) showed significant decreased in cholesterol, triglyceride and low density lipoprotein (LDL) as well as significant elevation of high density lipoprotein (HDL) levels relative to isoproterenol treated group of rats after 4 weeks $(p<0.05)$. Table (2) revealed a significant elevation in plasma aspartate aminotransferase (AST), lactate dehydrogenase (LDH) and creatine kinase-MB (CKMB) activities as well as plasma total protein level $(p<0.05)$ in the second group which represents isoproterenol $(100 \mathrm{mg} / \mathrm{kg})$ treated group of rats compared with control group. The administration of cranberry extract (75 and $150 \mathrm{mg} /$ kg.b.w. $)$ and vitamin $\mathrm{C} \quad(500$ and
$1000 \mathrm{mg} / \mathrm{kg}$ bw.) showed significant decreased in AST and LDH activities relative to isoproterenol treated group of rats after 4 weeks $(p<0.05)$. Tables $(3 \& 4)$ revealed a significant reduction in blood and heart catalase (CAT), glutathione peroxidase (GPx), superoxide dismutase (SOD) and reduced glutathione (GSH) as well as significant elevation of malondialdehyde (MDA) levels $(p<0.05)$ in the second group which represents isoproterenol $(100 \mathrm{mg} / \mathrm{kg})$ treated group of rats compared with control group. The administration of cranberry extract (75 and isoproterenol $(100 \mathrm{mg} / \mathrm{kg})$ treated group of rats after 4 weeks $(p<0.05)$.

Table (5) revealed a significant elevation in heart tumor necrosis factor-alpha (TNF- $\alpha$ ), nitric oxide (NO) and Interleukin-22 (IL-22) gene expression levels $(p<0.05)$ in the second group which represents isoproterenol $(100 \mathrm{mg} / \mathrm{kg})$ treated group of rats compared with control group. The administration of cranberry extract $(75$ and $150 \mathrm{mg} /$ kg.b.w.) and vitamin C (500 and $1000 \mathrm{mg} / \mathrm{kg}$ bw.) showed significant decreased in TNF- $\alpha$ and NO activities relative to isoproterenol group of rats after 4 weeks $(p<0.05)$. Also, (figures 21 and 22) revealed a significant depletion in heart total protein and blood hemoglobin levels $(p<0.05)$ in the second group which represents isoproterenol $(100 \mathrm{mg} / \mathrm{kg})$ treated group of rats compared with control group. The administration of cranberry extract (75 and $150 \mathrm{mg} / \mathrm{kg}$.b.w.) and vitamin C (500 and $1000 \mathrm{mg} / \mathrm{kg}$ bw.) showed significant increase in heart total protein and blood hemoglobin levels relative to isoproterenol group of rats after 4 weeks $(p<0.05)$.

Table 1. Effect of Cranberry extract and Vit C. on plasma triglycerides (TG), total Cholesterol (TC), HDLcholesterol (HDL-C) and LDL- cholesterol (LDL-C) in rats.

\begin{tabular}{|c|c|c|c|c|}
\hline Groups & $\begin{array}{l}\mathrm{TG} \\
(\mathrm{mg} / \mathrm{dl})\end{array}$ & $\mathrm{TC}(\mathrm{mg} / \mathrm{dl})$ & HDL-C (mg/dl) & $\begin{array}{l}\text { LDL-C } \\
(\mathrm{mg} / \mathrm{dl})\end{array}$ \\
\hline Normal & $115.00 \pm 13.48^{\mathrm{a}}$ & $106.70 \pm 13.87^{\mathrm{a}}$ & $31.20 \pm 4.21^{\mathrm{a}}$ & $52.51 \pm 10.25^{\mathrm{a}}$ \\
\hline $\begin{array}{l}\text { Control positive } \\
\text { ISO (100 mg/k.b.w.) }\end{array}$ & $175.32 \pm 11.82^{\mathrm{b}}$ & $169.17 \pm 15.41^{b}$ & $20.16 \pm 3.71^{\mathrm{b}}$ & $113.95 \pm 13.63^{b}$ \\
\hline $\begin{array}{l}\text { ISO (100 mg) + Cranberry extract (75 } \\
\mathrm{mg} / \mathrm{kg} . \text { b.w) }\end{array}$ & $109.48 \pm 6.84^{\mathrm{a}}$ & $115.02 \pm 12.40^{\mathrm{a}}$ & $29.88 \pm 4.69^{\mathrm{a}}$ & $61.58 \pm 12.43^{\mathrm{a}}$ \\
\hline $\begin{array}{l}\text { ISO }(100 \mathrm{mg})+\text { Cranberry extract (150 } \\
\mathrm{mg} / \mathrm{kg} . \text { b.w })\end{array}$ & $105.26 \pm 8.46^{\mathrm{a}}$ & $108.87 \pm 9.90^{\mathrm{a}}$ & $31.26 \pm 4.19^{\mathrm{a}}$ & $56.56 \pm 11.05^{\mathrm{a}}$ \\
\hline $\begin{array}{l}\text { ISO }(100 \mathrm{mg})+\text { Vit. C } \\
(500 \mathrm{mg} / \mathrm{kg} . \mathrm{b} . \mathrm{w})\end{array}$ & $108.99 \pm 9.94^{\mathrm{a}}$ & $111.27 \pm 9.57^{\mathrm{a}}$ & $32.69 \pm 5.87^{\mathrm{a}}$ & $56.78 \pm 11.18^{\mathrm{a}}$ \\
\hline $\begin{array}{l}\text { ISO }(100 \mathrm{mg})+\text { Vit. C } \\
(1 \mathrm{~g} / \mathrm{kg} . \text { b.w })\end{array}$ & $113.45 \pm 9.20^{\mathrm{a}}$ & $103.68 \pm 6.58^{\mathrm{a}}$ & $33.95 \pm 4.13^{\mathrm{a}}$ & $47.04 \pm 5.08^{c}$ \\
\hline
\end{tabular}

Data shown are mean \pm standard deviation of number of observations within each treatment. Data followed by the same letter are not significantly different at $P \leq 0.05$. Small letters are used for comparison between the means within the column. LDL-C (mmol/L) = TC-HDL- [TG/5]. 
Ali et al. (2017).

Table 2. Effect of cranberry extract and Vit C plasma activities of Aspartate aminotransferase (AST), Lactate dehydrogenase (LDH), creatine kinase-MB (CKMB)and level of total protein in rats

\begin{tabular}{lllll}
\hline Groups & $\begin{array}{l}\text { AST } \\
(\mathrm{U} / \mathrm{L})\end{array}$ & $\begin{array}{l}\text { LDH } \\
(\mathrm{U} / \mathrm{L})\end{array}$ & CKMB (U/L) & $\begin{array}{l}\text { Total protein } \\
(\mathrm{g} / \mathrm{dl})\end{array}$ \\
\hline Normal & $76.83 \pm 7.83^{\mathrm{a}}$ & $356.67 \pm 7.47^{\mathrm{a}}$ & $85.33 \pm 5.09^{\mathrm{a}}$ & $6.08 \pm 0.15^{\mathrm{a}}$ \\
& $170.00 \pm 5.83^{\mathrm{b}}$ & $954.00 \pm 12.76^{\mathrm{b}}$ & $343.50 \pm 38.89^{\mathrm{b}}$ & $5.08 \pm 0.12^{\mathrm{a}}$ \\
$\begin{array}{l}\text { Control positive } \\
\text { ISO (100 mg/k.b.w.) }\end{array}$ & & & \\
$\begin{array}{l}\text { ISO (100 mg) + Cranberry extract }(75 \\
\text { mg/kg.b.w) }\end{array}$ & $153.33 \pm 3.56^{\mathrm{c}}$ & $595.00 \pm 10.89^{\mathrm{c}}$ & $228.33 \pm 2.58^{\mathrm{c}}$ & $5.30 \pm 0.14^{\mathrm{a}}$ \\
$\begin{array}{l}\text { ISO (100 mg) + Cranberry extract }(150 \\
\text { mg/kg.b.w) }\end{array}$ & $144.17 \pm 3.06^{\mathrm{c}}$ & $515.83 \pm 10.68^{\mathrm{d}}$ & $214.00 \pm 4.86^{\mathrm{d}}$ & $5.48 \pm 0.12^{\mathrm{a}}$ \\
$\begin{array}{l}\text { ISO (100 mg) + Vit. C } \\
(500 \mathrm{mg} / \mathrm{kg} . \mathrm{b} . w)\end{array}$ & $134.83 \pm 2.32^{\mathrm{d}}$ & $465.67 \pm 6.89^{\mathrm{e}}$ & $122.50 \pm 3.51^{\mathrm{d}}$ & $5.73 \pm 0.12^{\mathrm{a}}$ \\
$\begin{array}{l}\text { ISO (100 mg) + Vit. C } \\
(1 \mathrm{~g} / \mathrm{kg} . \mathrm{b} . \mathrm{w})\end{array}$ & $121.17 \pm 2.64^{\mathrm{e}}$ & $380.00 \pm 5.25^{\mathrm{f}}$ & $99.67 \pm 7.12^{\mathrm{a}}$ & $6.15 \pm 0.19^{\mathrm{a}}$
\end{tabular}

Data shown are mean \pm standard deviation of number of observations within each treatment. Data followed by the same letter are not significantly different at $P \leq 0.05$. Small letters are used for comparison between the means within the column.

Table 3. Effect of cranberry extract and Vit $\mathrm{C}$ on blood catalase (CAT), glutathione peroxidase (GPx) and superoxide dismutase (SOD) activities as well as levels of reduced Glutathione (GSH) and plasma thiobarbituric acid reactive substances (TBARS) in rats

\begin{tabular}{|c|c|c|c|c|c|}
\hline Groups & $\begin{array}{l}\text { CAT } \\
(\mathrm{U} / \mathrm{g} \mathrm{Hb})\end{array}$ & $\begin{array}{l}\text { GPx } \\
(\mathrm{U} / \mathrm{g} \mathrm{Hb})\end{array}$ & $\begin{array}{l}\text { SOD } \\
(\mathrm{U} / \mathrm{g} \mathrm{Hb})\end{array}$ & $\begin{array}{l}\mathrm{GSH} \\
(\mathrm{mg} \%)\end{array}$ & $\begin{array}{l}\text { TBARS } \\
(\mathrm{nmol} / \mathrm{L})\end{array}$ \\
\hline Normal & $16.36 \pm 2.09^{a}$ & $151.39 \pm 10.86^{\mathrm{a}}$ & $9.00 \pm 1.73^{\mathrm{a}}$ & $9.28 \pm 2.25^{\mathrm{a}}$ & $4.68 \pm 0.91^{\mathrm{a}}$ \\
\hline $\begin{array}{l}\text { Control positive } \\
\text { ISO (100 mg/k.b.w.) }\end{array}$ & $6.58 \pm 1.30^{\mathrm{b}}$ & $92.78 \pm 14.25^{\mathrm{b}}$ & $4.28 \pm 0.89^{b}$ & $3.96 \pm 0.54^{\mathrm{b}}$ & $8.27 \pm 1.40^{b}$ \\
\hline $\begin{array}{l}\text { ISO }(100 \mathrm{mg})+\text { Cranberry } \\
\text { extract }(75 \mathrm{mg} / \mathrm{kg} . \text { b.w })\end{array}$ & $11.13 \pm 1.36^{\mathrm{c}}$ & $127.36 \pm 12.31^{\mathrm{c}}$ & $6.26 \pm 0.76^{\mathrm{c}}$ & $6.22 \pm 1.00^{\mathrm{c}}$ & $5.47 \pm 1.06^{\mathrm{a}}$ \\
\hline $\begin{array}{l}\text { ISO }(100 \mathrm{mg})+\text { Cranberry } \\
\text { extract }(150 \mathrm{mg} / \mathrm{kg} . \text { b.w })\end{array}$ & $16.48 \pm 1.41^{\mathrm{a}}$ & $148.24 \pm 10.98^{\mathrm{d}}$ & $8.24 \pm 1.12^{\mathrm{a}}$ & $9.29 \pm 2.65^{\mathrm{a}}$ & $4.41 \pm 0.52^{\mathrm{a}}$ \\
\hline $\begin{array}{l}\text { ISO }(100 \mathrm{mg})+\text { Vit. C } \\
(500 \mathrm{mg} / \mathrm{kg} . \text { b.w })\end{array}$ & $8.35 \pm 1.48^{\mathrm{d}}$ & $124.84 \pm 12.22^{\mathrm{c}}$ & $6.33 \pm 0.99^{c}$ & $6.01 \pm 1.62^{\mathrm{c}}$ & $4.71 \pm 0.98^{\mathrm{a}}$ \\
\hline $\begin{array}{l}\text { ISO }(100 \mathrm{mg})+\text { Vit. C } \\
(1 \mathrm{~g} / \mathrm{kg} . \mathrm{b} . \mathrm{w})\end{array}$ & $14.16 \pm 2.25^{\mathrm{a}}$ & $136.33 \pm 14.52^{\mathrm{d}}$ & $8.94 \pm 0.97^{\mathrm{ac}}$ & $10.42 \pm 2.70^{\mathrm{a}}$ & $4.35 \pm 0.74^{\mathrm{a}}$ \\
\hline
\end{tabular}

Data shown are mean \pm standard deviation of number of observations within each treatment. Data followed by the same letter are not significantly different at $\mathrm{P} \leq 0.05$. Small letters are used for comparison between the means within the column.

Table 4. Effect of cranberry extract and Vit C on heart catalase (CAT), glutathione peroxidase (GPx) and superoxide dismutase (SOD) activities as well as levels of reduced Glutathione (GSH) and thiobarbituric acid reactive substances (TBARS) in rats

\begin{tabular}{|c|c|c|c|c|c|}
\hline Groups & $\begin{array}{l}\text { CAT } \\
\text { (U/mg } \\
\text { protein) }\end{array}$ & $\begin{array}{l}\text { GPx } \\
\text { (U/mg } \\
\text { protein) }\end{array}$ & $\begin{array}{l}\text { SOD } \\
\text { (U/mg } \\
\text { protein) }\end{array}$ & $\begin{array}{l}\text { GSH } \\
\text { (umol/mg } \\
\text { protein) }\end{array}$ & $\begin{array}{l}\text { TBARS }(\mathrm{nmol} / \mathrm{mg} \\
\text { protein) }\end{array}$ \\
\hline Normal & $11.46 \pm 2.41^{\mathrm{a}}$ & $3.21 \pm 0.37^{\mathrm{a}}$ & $5.64 \pm 0.76^{a}$ & $5.64 \pm 0.76^{\mathrm{a}}$ & $51.61 \pm 8.87^{\mathrm{a}}$ \\
\hline $\begin{array}{l}\text { Control positive } \\
\text { ISO (100 mg/k.b.w.) }\end{array}$ & $3.5 \pm 0.87^{b}$ & $1.58 \pm 0.35^{\mathrm{b}}$ & $2.91 \pm 0.84^{b}$ & $2.73 \pm 0.39^{b}$ & $96.38 \pm 10.54^{b}$ \\
\hline $\begin{array}{l}\text { ISO }(100 \mathrm{mg})+\text { Cranberry } \\
\text { extract }(75 \mathrm{mg} / \mathrm{kg} . \text { b.w })\end{array}$ & $5.40 \pm 0.69^{c}$ & $2.59 \pm 0.47^{\mathrm{c}}$ & $4.08 \pm 0.80^{\mathrm{a}}$ & $3.70 \pm 0.67^{\mathrm{c}}$ & $71.64 \pm 7.20^{\mathrm{c}}$ \\
\hline $\begin{array}{l}\text { ISO }(100 \mathrm{mg})+\text { Cranberry } \\
\text { extract }(150 \mathrm{mg} / \mathrm{kg} . \text { b.w })\end{array}$ & $11.01 \pm 1.36^{\mathrm{a}}$ & $3.42 \pm 0.66^{\mathrm{a}}$ & $5.46 \pm 0.79^{\mathrm{a}}$ & $5.07 \pm 0.90^{\mathrm{a}}$ & $52.40 \pm 4.30^{\mathrm{a}}$ \\
\hline $\begin{array}{l}\text { ISO }(100 \mathrm{mg})+\text { Vit. C } \\
(500 \mathrm{mg} / \mathrm{kg} . \text { b.w })\end{array}$ & $9.69 \pm 1.63^{a}$ & $2.44 \pm 0.37^{\mathrm{c}}$ & $4.56 \pm 0.61^{\mathrm{a}}$ & $4.11 \pm 0.68^{\mathrm{a}}$ & $66.65 \pm 9.41^{\mathrm{ac}}$ \\
\hline $\begin{array}{l}\text { ISO }(100 \mathrm{mg})+\text { Vit. C } \\
(1 \mathrm{~g} / \mathrm{kg} . \text { b.w })\end{array}$ & $10.86 \pm 1.23^{\mathrm{a}}$ & $3.35 \pm 0.48^{\mathrm{a}}$ & $5.25 \pm 0.74^{\mathrm{a}}$ & $4.51 \pm 0.49^{\mathrm{a}}$ & $57.69 \pm 6.79^{\mathrm{a}}$ \\
\hline
\end{tabular}


Table 5. Effect of Cranberry extract and Vit C. on heart tumor necrosis factor-alpha (TNF- $\alpha$ ), nitric oxide (NO).

\begin{tabular}{|c|c|c|c|c|c|}
\hline Groups & $\begin{array}{l}\text { TNF- } \alpha \\
\text { (pg/mg protein) }\end{array}$ & $\begin{array}{l}\mathrm{NO} \\
\text { (ug/mg protein) }\end{array}$ & $\begin{array}{l}\text { Total Protein } \\
\text { (mg/g tissue) }\end{array}$ & IL-22 & $\begin{array}{l}\mathrm{Hb} \% \\
(\mathrm{~g} / \mathrm{dl})\end{array}$ \\
\hline Normal & $332.62 \pm 16.84^{a}$ & $117.53 \pm 8.55^{\mathrm{a}}$ & $99.38 \pm 3.18^{\mathrm{a}}$ & $1.03 \pm 0.03^{\mathrm{a}}$ & $13.73 \pm 1.00^{\mathrm{a}}$ \\
\hline $\begin{array}{l}\text { Control positive } \\
\text { ISO (100 mg/k.b.w.) }\end{array}$ & $522.37 \pm 20.76^{b}$ & $158.77 \pm 7.26^{\mathrm{b}}$ & $70.90 \pm 7.92^{b}$ & $13.43 \pm 3.66^{\mathrm{b}}$ & $11.10 \pm 0.51^{\mathrm{a}}$ \\
\hline $\begin{array}{l}\text { ISO }(100 \mathrm{mg})+ \\
\text { Cranberry extract }(75 \\
\text { mg/kg.b.w) }\end{array}$ & $348.26 \pm 16.07^{\mathrm{a}}$ & $139.82 \pm 10.12^{\mathrm{c}}$ & $87.69 \pm 8.94^{\mathrm{ab}}$ & $5.63 \pm 0.48^{c}$ & $12.64 \pm 0.63^{\mathrm{a}}$ \\
\hline $\begin{array}{l}\text { ISO }(100 \mathrm{mg})+ \\
\text { Cranberry extract }(150 \\
\text { mg/kg.b.w) }\end{array}$ & $345.12 \pm 17.83^{\mathrm{a}}$ & $121.01 \pm 8.72^{\mathrm{a}}$ & $94.03 \pm 7.13$ ac & $5.67 \pm 0.42^{\mathrm{c}}$ & $13.01 \pm 0.37^{\mathrm{a}}$ \\
\hline $\begin{array}{l}\text { ISO }(100 \mathrm{mg})+\text { Vit. C } \\
(500 \mathrm{mg} / \mathrm{kg} . \mathrm{b} . \mathrm{w})\end{array}$ & $370.32 \pm 10.32^{\mathrm{c}}$ & $131.13 \pm 7.70^{\text {ac }}$ & $88.36 \pm 5.34$ ab & $4.03 \pm 1.06^{\mathrm{c}}$ & $\begin{array}{l}13.33 \pm \\
0.54^{\mathrm{a}}\end{array}$ \\
\hline $\begin{array}{l}\text { ISO }(100 \mathrm{mg})+\text { Vit. C } \\
(1 \mathrm{~g} / \mathrm{kg} . \text { b.w })\end{array}$ & $349.89 \pm 16.00^{\mathrm{a}}$ & $120.81 \pm 4.53^{\mathrm{ac}}$ & $\begin{array}{l}96.70 \pm 10.77 \\
\text { abc }\end{array}$ & $3.00 \pm 1.39^{\mathrm{d}}$ & $\underset{\mathrm{a}}{13.38 \pm 0.54}$ \\
\hline
\end{tabular}

\section{DISCUSSION}

Oxidative stress has been associated with diverse pathophysiological events, including cancer, renal disease and neuro-degeneration (Griendling and FitzGerald, 2003). It has been established that excessive oxidative stress caused by either increased ROS production or inadequate antioxidant defenses can lead to cardiac lesions (Wheatley et al., 1985). The Present study demonstrates the cardioprotective effect of cranberry extract in isoproterenol-induced cardio toxicity as evidenced by improved antioxidant defense as well as inhibition of lipid peroxidation and prevention of leakage of myocytes injury marker enzymes from heart.

Lipid peroxidation may damage membranes in other cells, altering important elements of control for blood pressure. Both Britton et al. (1987); Brunet et al. (1999) found the same results. Yates and Dhalla (1975) have explained that isoproterenol undergoing oxidation results in the formation of superoxide anion and the chain reactions propagate results in the formation of reactive oxygen species. In the present study, the increased level of oxidative stress markers observed in isoproterenol-injected rats might be due to the generated free radicals from autooxidation of isoproterenol.

Since cranberry has shown antioxidant and free radical scavenging activity (Sies, 1997), the present study ameliorating the effect of cranberry' polyphenols on isoproterenol induced heart toxicity in rat was studied. Oral administration of cranberry extract significantly inverse the isoproterenol induced peroxidative damage in heart which is evidenced from the lowered levels of thiobarbituric acid reactive substances.

This may be due to the anti-oxidative effect of polyphenols (Veerappan et al., 2004). An antioxidant is a molecule capable of slowing or preventing the oxidation of other molecules. Oxidation is a chemical reaction that transfers electrons from a substance to an oxidizing agent. Isoproterenol induces cellular injury and functional abnormalities in hepatocytes by the process of lipid peroxidation (Hussein, 2010). Because the heart has a central role in the maintenance of lipid homeostasis, excess iron may alter the concentration of serum lipids, which could reduce or increase the risk of atherosclerosis.

The primary antioxidant enzymes in mammals include SOD which converts superoxide to hydrogen peroxide, GPx and CAT which are responsible for converting hydrogen peroxide to water (Formigari et al., 2007). GSH is a very important non-enzymatic antioxidant which can react directly with free radicals or act as an electron donor in the reduction of peroxides catalyzed by GPx (Dringen, 2000). The present results show marked decreased plasma and heart SOD, GPx, CAT and GSH level indicating acute cardiotoxicity in isoproterenol-treated group. The obtained data in the present study demonstrated that cranberry extract considered as a potent antioxidant agent when given simultaneously with isoproterenol since it could produce marked increase in plasma and heart SOD, GPx, CAT and GSH levels towards the normal values.

These findings confirm the onset of myocardial necrosis and leaking out of the marker enzymes from heart to blood (SabeenaFarvin et al., 2004). 
The amount of marker enzymes is directly proportional to isoproterenol induced necrotic lesions present in the myocardium. In the present study, pretreatment of cranberry extract to myocardial infarction-induced rats reduce the cardiac damage and restrict the leakage of enzymes as evident from a significant reduction in the activities of cardiac marker enzymes in plasma.CK-MB and $\mathrm{LDH}$, localized in myocytes, are released during isoproterenol-induced irreversible myocardial injury and are considered as characteristic of cardiac muscle injury (Tonomura et al., 2009).

Due to disruption of endogenous antioxidant network, as observed in present study significant increase of TNF- $\alpha$ and NO levels in isoproterenol treated rats compared with negative control group of rats. Isoproterenol induced myocardial toxicity may be more susceptible to free radicals induced ischemic injury and subsequent cascade of inflammation and injury. Inflammation is the very initial response of the immune system to infection. The anti-inflammatory effect of cranberry extract containing polyphenols has been documented as a good anti-inflammatory phytocompounds (AbdelMaksoud et al., 2015; Vinson et al., 2001). The present study findings demonstrate therapeutic benefits of cranberry extract an integrated approach as evidenced by restoration and improvement of TNF- $\alpha$ and nitric NO as well as endogenous antioxidant defense and inhibition of lipid peroxidation. In conclusion, our study clearly demonstrates that cranberry extract administration to isoproterenol-induced rats for 28 days possess significant cardio protection by minimizing the alterations in the activities of the antioxidant enzymes. These effects could be due to membrane protective action of cranberry extract by scavenging the free radicals and its antioxidant action.

\section{REFERENCES}

Abdel-Maksoud, H.A., Hussein, M.A., Mahmoud, A.B., 2015. Cranberry Extract as a Functional Food in Treatment of Myocardial Toxicity Induced by nicotine in Rats. International Journal of Pharma Sciences 5 1174-1180.

Alcantara, E., Shin, M., Sohn, H., Park, Y., Kim, T., Lim, J., Jeong, H., Kwon, S., Kwun, I., 2011. Diosgenin stimulates osteogenic activity by increasing bone matrix protein synthesis and bone-specific transcription factor Runx2 in osteoblastic MC3T3-E1 cells. J NutrBiochem 22, 1055-1063.
Allain, C.C., Poon, L.S., Chan, C.S., Richmond, W., Fu, P.C., 1974. Enzymatic determination of total serum cholesterol. Clin Chem 4, 470-475.

Almagro, L., Fernandez-Perez, F., Pedreno, M.A., 2015. Indole alkaloids from Catharanthusroseus: Bioproduction and their effect on human health. Molecules 2015 20, 2973-3000.

Berenson, G.S., Srinivasan, S.R., Bao, W., Newman, W.P., Tracy, R.E., 1998. Association between multiple cardiovascular risk factors and atherosclerosis in children and young adults. The Bogalusa Heart Study. N Engl J Med. 338, 1650-1656.

Beyaert, R., Fiers, W., 1998. Tumor Necrosis Factor and Lymphotoxin. In Cytokines, A.R.M.-S. a. R. Thorpe, eds. Academic Press, San Diego.

Britton, R.S., Bacon, B.R., Recknagel, R.O., 1987. Lipid peroxidation and associated hepatic organelle dysfunction in iron overload. Chem. Phys. Lipids 45, 207-239.

Brunet, S., Thibault, L., Delvin, E., Yotov, W., Bendayan, M., Levy, E., 1999. Dietary iron overload and induced lipid peroxidation are associated with impaired plasma lipid transport and hepatic sterol metabolism in rats. Hepatology 29, $1809-1817$.

Burnstein, M., Selvenick, H., Morfin, R., 1970. Rapid method for isolation of lipoprotein from human serum with polyanions. J Lipid Res. 11, 583- 395.

Chanarin, I., 1989. Text book of Laboratory Haematology: An Account of Laboratory techniques. Churchill Livingstone, New York.

Chen, L., Hu, J.Y., Wang, S.Q., 2012. The role of antioxidants in photoprotection: A critical review. J Am Acad Dermatol 23, 231-240.

da Silva, N.A., da Silva, J.K., Andrade, E.H., 2009. Essential oil composition and antioxidant capacity of Lippiaschomburgkiana. Nat Prod Commun. 4, 1281-1286.

De'corde', K., Agne, A., Lacan, D., 2009. Preventive effect of a melon extract rich in superoxide scavenging activity on abdominal and liver fat and adipokine imbalance in high-fat-fed hamsters. J Agric Food Chem. 22, 6461-6467.

Dringen, R., 2000. Metabolism and functions of glutathione in brain. Prog Neurobiol 62, 649-671.

Ebenezer, O., Farombi, A., Olatunde, 2011. Antioxidative and Chemopreventive Properties of Vernoniaamygdalina and 
Garciniabiflavonoid. Int. J. Environ. Res. Public Health. 8, 2533-2555.

Ebrahimzadeh, M.A., Nabavi, S.F., Nabavi, S.M., 2009. Essential oil composition and antioxidant activity of Pterocaryafraxinifolia. Pak J Biol Sci. 12, 957-963.

Formigari, A., Irato, P., Santon, A., 2007. Zinc, antioxidant systems and metallothionein in metal mediated-apoptosis: biochemical and cytochemical aspects. Comp Biochem Physiol C Toxicol Pharmacol 146, 443-459.

Fossati, P., Prencipe, L., 1982. Serum triacylglycerols determined calorimetrically with an enzyme that produces hydrogen peroxide. Clin Chem 1, 2077-2080.

Gerhardt, W., Waldenström, J., 1979. Creatine kinase B-subunit activity in serum after immunoinhibition of M-subunit activity. Clin Chem 25, 1274-1280.

Griendling, K.K., FitzGerald, G.A., 2003. Oxidative stress and cardiovascular injury: Part I: basic mechanisms and in vivo monitoring of ROS. Circulation 108, 19121916.

Han, S.H., Yang, B.S., Kim, H.J., 2003. Effectiveness of aromatherapy massage on abdominal obesity among middle aged women. J Korean Acad Nurss 33, 839-846.

Hussein, M.A., 2010. Purslane Extract Effects on Obesity-Induced Diabetic Rats Fed a HighFat Diet. Mal J Nut. 3, 419-429.

King, J., 1965. The dehydrogenase or oxidoreductatse. Lactate dehydrogenase. In: Practical clinical enzymology. Nostr. and Co., London.

Liu, Y.T., 2013. The metabolic disturbances of isoproterenol induced myocardial infarction in rats based on a tissue targeted metabonomics. Mol. Biosyst. 9, 2823-2834.

Luo, Z., Harada, T., London, S., 1995. Antioxidant and iron chelating agents in cerebral vasospasm. Neurosurgery 37, 1054.

Marklund, S., Marklund, D., 1974. Involvement of the superoxide anion radical in the autoxidation of pyrogallol and a convenient assay for superoxide dismutase. Eur. J. Biochem. 47, 469.

Mates, J., M, , Perez-Gomez, C., Nunez de Castro, I., 1999. Antioxidant enzymes and human diseases. Clin Biochem 32, 595-603.

Miranda, K.M., Espey, M.G., Wink, D.A., 2001. A rapid, simple spectrophotometric method for simultaneous detection of nitrate and nitrite. Nitric Oxide 5, 62-71.

Naghavi, M., Libby, P., Falk, E., Casscells, S., Litovsky, S., 2003. From vulnerable plaque to vulnerable patient: a call for new definitions and risk assessment strategies. Part I. Circulation 108, 1664-1672.

Neto, C.C., Sweeney-Nixon, M.I., Lamoureaux, T.L., 2005. Cranberry phenolics: Effects on oxidative processes, neuron cell death and tumor cell growth. In Shahidi F, Ho C-T, editors. Symposium Series No. 909. Phenolic Compounds in Foods and Natural Health Products Columbus, OH: ACS Books 4, 271-282.

Nichans, W.H., Samulelson, B., 1968. Formation of malondialdehyde from phospholipid arachidonate during microsomal lipid peroxidation. Eur J Biochem 6, 126-130.

Porter, M.L., Krueger, C.G., Wiebe, D.A., 2001. Cranberry proanthocyanidins associate with low-density lipoprotein and inhibit in vitro $\mathrm{Cu} 2$ 1-induced oxidation. J Sci Food Agric. 81, 1306-1313.

Reitman, S., Frankel, S., 1957. A colorimetric method for the determination of serum glutamic oxalacetic and glutamic pyruvic transaminases. Am J Clin Pathol 28, 56-63.

SabeenaFarvin, K.H., Anandan, R., Kumar, S.H., Shiny, K.S., Sankar, T.V., 2004. Effect of squalene on tissue defense system in isoproterenol-induced myocardial infarction in rats. Pharmacol Res 50, 231-236.

Sathish, V., Ebenezar, K.K., Devaki, T., 2003. Synergistic effect of nicorandil and amlodipine on tissue defense system during experimental myocardial infarction in rats. Mol Cell Biochem 243, 133-138.

Seef, L.B., Lindsay, K.L., Bacon, B.R., 2001. Complementary and alternative medicine in chronic liver disease. Hepatology 34, 595603.

Sies, H., 1997. Oxidative stress, oxidants and antioxidants. Exp. Physiol. 82, 291-295.

Sinha, A.K., 1972. Colorimetric assay of catalase. J. Anal Biochem. 47, 389-394.

SPSS, 2012. SPSS 15, Inc. Chicago, IL, USA.

Tonomura, Y., Mori, Y., Torii, M., Uehara, T., 2009. Evaluation of the usefulness of biomarkers for cardiac and skeletal myotoxicity in rats. Toxicology 266, 48-54.

Van Kampen, E.J., Zijlstra, W.G., 1961. Standardization of hemoglobinometry II. The hemiglobin-cyanide method. Clin. Chim. Acta 6, 538- 544.

Veerappan, R.M., Senthil, S., Rao, M., Ravikumar, M., 2004. Redox status and lipid peroxidation in alcoholic hypertensive patients and alcoholic hypertensive patients with diabetes. Clin. Chem. Acta 340, $207-$ 212. 
Vinson, J.A., Su, X., Zubik, L., 2001. Phenol antioxidant quantity and quality in foods: Fruits. J. Agric. Food Chem. 49, 5315-5321.

Weichselbaum, T.E., 1946. An accurate and rapid method for the determination of proteins in small amounts of blood, serum and plasma. Am. J. Clin. Pathol. 16, 40-49.

Wheatley, A.M., Thandroyen, F.T., Opie, L.H., 1985. Catecholamine-induced myocardial cell damage: catecholamines or adrenochrome. J Mol Cell Cardiol 17, 349359.

Yan, X., Murphy, B.T., Hammond, G.B., 2002. Antioxidant activities and antitumor screening of extracts from cranberry fruit (Vacciniummacrocarpon). J Agric Food Chem. 50, 5844-5849.

Yates, J.C., Dhalla, N.S., 1975. Induction of necrosis and failure in the isolated perfused rat heart with oxidized isoproterenol. J Mol Cell Cardiol 7, 807-816.

Youdim, K.A., McDonald, J., Kalt, W., 2002. Potential role of dietary flavonoids in reducing microvascular endothelium vulnerability to oxidative and inflammatory insults. J Nutr Biochem. 13, 282-288. 